\title{
CREATIVE ACCOUNTING, AN EXPRESSION OF THE DISCONNECTION BETWEEN ACCOUNTING AND TAXATION
}

\author{
Adrian Groşanu ${ }^{1}$ \\ Paula Ramona Răchişan ${ }^{2}$ \\ Sorin Romulus Berinde
}

\begin{abstract}
In the context of a developed capital market, the dimensioning of the accounting profit is very important for investors, considering the financing of the economic entities to a higher degree than that offered by the banking system. We intend to emphasize some risks that appear from the perspective of creative accountancy (an expression of the disconnection between accountancy and taxation). The risks consist in some less ethical tendencies of artificially oversizing and undersizing the accounting and the tax profit according to certain objectives, risks that can be controlled through a better activity of accounting regulations. We can say that the accounting result can be influenced in the case of a taxation connected ratio. On the other hand, the accounting result is subject to an increasing risk due to the creative accounting. Under these circumstances, a question appears: Which risk is better to be assumed taking into account the dimension of the accounting result?
\end{abstract}

Key words: Financial Regulations, Accounting Result, Investors, True and Fair Value, Risks

Cod JEL: M41

\section{Introduction - The Taxation - Accounting Report}

Both specialized literature and practice have highlighted the conflicts generated by the accounting-taxation report. Most times, it is considered that a fundamental cause that generates the conflict between them is due to the fact that the principles, rules and regulations of these two disciplines have different purposes and their convergence is difficult.

Basically, accounting has as main objective providing information for the users of financial situations, the shareholders and investors being as users with the highest level of information required. At the same time, the taxation, as an attribute of the state, is also interested in financial statements and information provided by accounting, but in a completely different perspective (Ristea M. et al, 2005). Therefore, we can affirm that the relationship between accounting and taxation is one of interdependence.

Starting from the consideration that the accounting result is basis for the establishment of the tax result (profit or tax loss), it is useful to mention some factors that directly influence the accounting result, and indirectly the result of tax:

- subjective factors (the nature of current economic and political systems, the way of governing the enterprise, the counterpower elements);

- objective factors (understandings of the determination of the accounting result, the principles that intervene in its determination process, and the adopted accounting conventions and policies.

\footnotetext{
1 Babeş-Bolyai University, Faculty of Economic Sciences and Business Administration, Cluj-Napoca, Romania, e-mail: adrian.grosanu@econ.ubbcluj.ro

${ }^{2}$ Babeş-Bolyai University, Faculty of Business, Cluj-Napoca, Romania, e-mail: ramona.rachisan@tbs.ubbcluj.ro

${ }^{3}$ Babeş-Bolyai University, Faculty of Business, Cluj-Napoca, Romania, e-mail: sorin.berinde@tbs.ubbcluj.ro
} 
The elements that directly influence the dimension of the accounting result and indirectly the dimension of tax result (because it is basis for calculating the accounting result), as well as the orientation trends under these influences can be summarized as follows:

\begin{tabular}{|ccc|}
\hline INFLUENCE & & $\begin{array}{c}\text { PREVAILING } \\
\text { FENDENCR }\end{array}$ \\
Accounting & & \\
Creativity & $\rightarrow$ & Increase \\
Taxation & $\rightarrow$ & Decrease \\
Inflationary & & Increase \\
phenomenon & $\rightarrow$ & \\
\hline
\end{tabular}

\section{Figure no.1. - Influence factor of result (authors processings)}

Starting from this classification of factors which directly influence the dimension of accounting result (and indirectly the tax result) is established a variety of patterns for determining the accounting and tax profits. In this context, some are adapted to inflation (purchasing power, current cost in real terms), others are adapted to the disconnection situations of taxation accounting (taking into account the temporary differences).

The conclusion of these considerations consists in the need to preserve an equidistance dimensioning of profit between connection (the risk is concretized by fiscal regulations) and disconnection (the risk of being represented by the creative accounting).

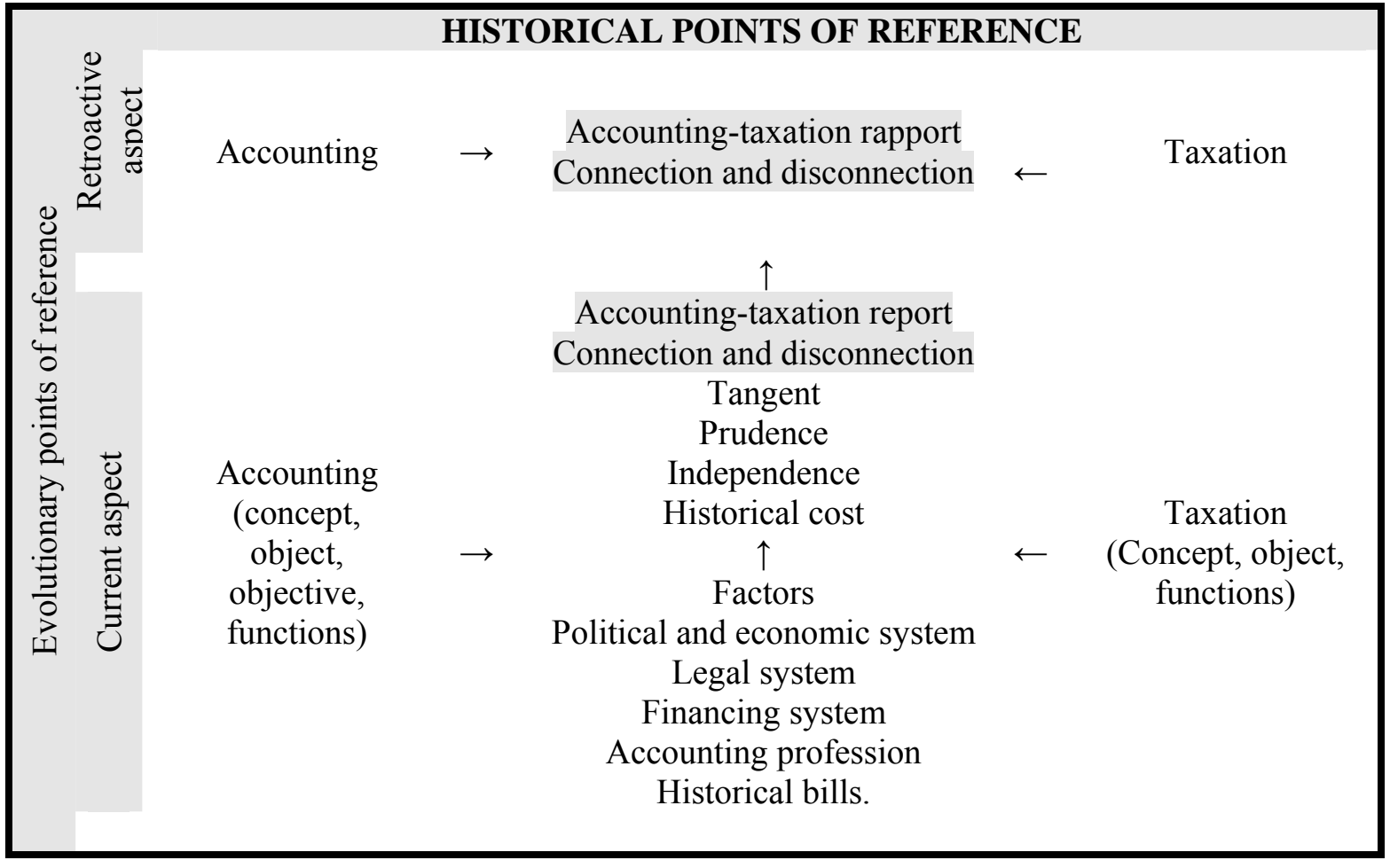




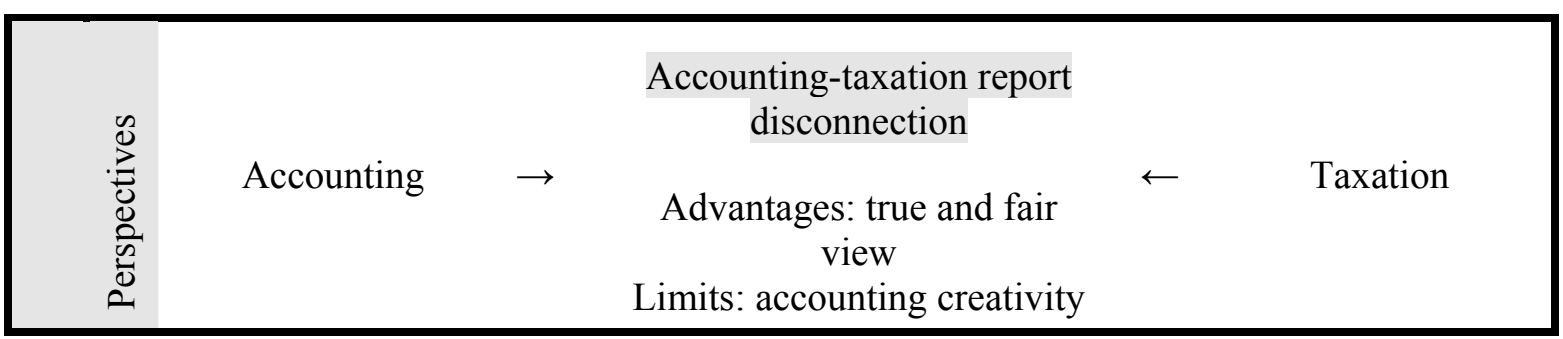

Figure no.2.- Approaching the accounting-taxation report, general and particular case of Romania (authors processings)

\section{Methodology research}

The research activity for establishing theories and verification of the ability to implement, can be generally classified according to the reference point in two major categories: deductive research (from theory to practice) and inductive research (from practice to theory).

Concerning these aspects we mentioned the existence of a connection between the typology of research and the report tax-accounting. It is known that the inductive research starts from practical events and its objective is the formulation of theories (Malcolm S., 2005). This approach requires the analysis of accounting practice, of the way it is reflected in accounting terms a certain event in theory, when regulations are deficient or missing. Therefore on this basis are summarized the best solutions underlying assessment of new accounting regulations that will influence practice. A concrete example of accounting inductivism mentioned by specialists is the accounting plan, which originates from the continental accounting system, which includes its connection to the accounting system connected to fiscality. It is known the fact that the preferential recipient of accounting information is in this situation the institution of state. Therefore we emphasize that there is a relationship of dependency between the accounting inductivism and the connection of accounting to fiscality.

On the other hand, the deductive research requires the formulation of accounting theories which have as utility improving the accounting practice. The initial theoretical basis will be subsequent checked each time when a practical event requires the implementation of theory initially issued. An example of application of accounting deductivism is represented by elaboration of the accounting conceptual framework, with a high degree of generality. A well elaborated conceptual framework is specific to accounting systems which originates from Anglo-Saxon, disconnected from fiscality. The preferential users of accounting information are in this case the investors and the creditors. Therefore we emphasize that there is a relationship of dependency between accounting deductivism and the accounting connection to fiscality. By reference to these aspects, the content work will be based on a deductive research, starting from theory toward practice, with some tendency towards the inductive research which consist in case practical studies conceived in order to verify the measure in which theoretical certain aspects mentioned above are validated from practical point of view. This type of research which consists in combining the deductive trend with the inductive trend is known the specialized literature under the term "composite research".

\section{Literature review}

The concept of creative accounting has British origins and it represents the object of long lectures within British literature. This term is complemented by several concepts, most common being "imaginative accounting" and "accounting of intent". Regarding the existence of this concept, the opinions are divided: some accept the existence of creative accounting, others deny it. We consider significant the opinion of Herve Stolowy when the existence of creative accounting is not accepted. He mentions that:

- $\quad$ frauds have nothing creative: they are illegal; illegal techniques, frauds and other artifices have nothing creative in their mechanism; 
- $\quad$ accounting options have always existed and they do not represent creative accounting [...] the option principle has been known and applied by accountants for a long time;

- the implicit subjectivity of evaluation is unavoidable and it has always existed;" (Stolowy H., 1994). The specialists who accept the idea of creative accounting existence underlines the necessity of a differentiation between real frauds and forgeries, between legal "adjustments" of the accounts and creative accounting, mentioning, at the same time, the danger of confusing the "accounting adjustments to judicial, economic and financial developments, with abuses - more or less conscious - and deliberate fraud" (Feleagă N., 1996).

The advocates of creative accounting existence agree that the premises of its emerging are the following:

- the necessity of using the imagination of accounting specialists to translate those legal, economic and financial innovations for which there are not, at the moment of their emerging, standardized accounting solutions. Thus, practice creates situations without precedent that the accounting theory must take into account (Harvey D.et al, 2001);

- using or not using the assemblies resulting from this financial engineering, depending on their incidence on the financial statements of the company (Solomons D., 1989).

- the priority of professional judgment regarding the financial-accounting reporting of economic events;

- the tendency of increasing accounting profits, even at the risk of increasing the tax burden at the expense of diminishing trend of taxable supply.

As it can be seen the appearance premises of creative accounting have existed where the state implication degree within the process of accounting regulation was minimal, which is where accounting is not influenced by fiscal regulations and hence the motivation of the idea that creative accounting originally appeared in Anglo-Saxon system (David A., Britton A., 2002). According to subsequent argumentations, the accounting system disconnected from the taxation system has its pitfalls concerning the objectivity of accounting information. This fact is reflected by a stronger predisposition to accounting creativity, existing the possibility to influence financial situations in order to primary transmit information to certain preferential categories of users Walton P. et al, 2003). The consequence is not achieving the basic objective of accounting: the true and fair view, where we can deduce that the Anglo-Saxon equivalent of the tax pollution risk, specific to continental system, can be represented in some creative accounting conditions.

\section{The limits of the disconnection between accounting and taxation: creative accounting}

After discussing about the two extreme situations previously presented the question that arises is: towards which extreme the shaping techniques of the accounting result would be opportune? It is preferable the tendency to disconnect or to connect? Or none of these options, given that each has both advantages and disadvantages? Starting from the mentioned opinions and argumentations, we conclude by expressing our option for the necessity of releasing accounting, and thus, the accounting result, both from the fiscal influences specific to systems connected to taxation, and from creativity, preponderant risk specific to accounting systems disconnected from taxation, an idea which is schematically presented according to the following situation: 


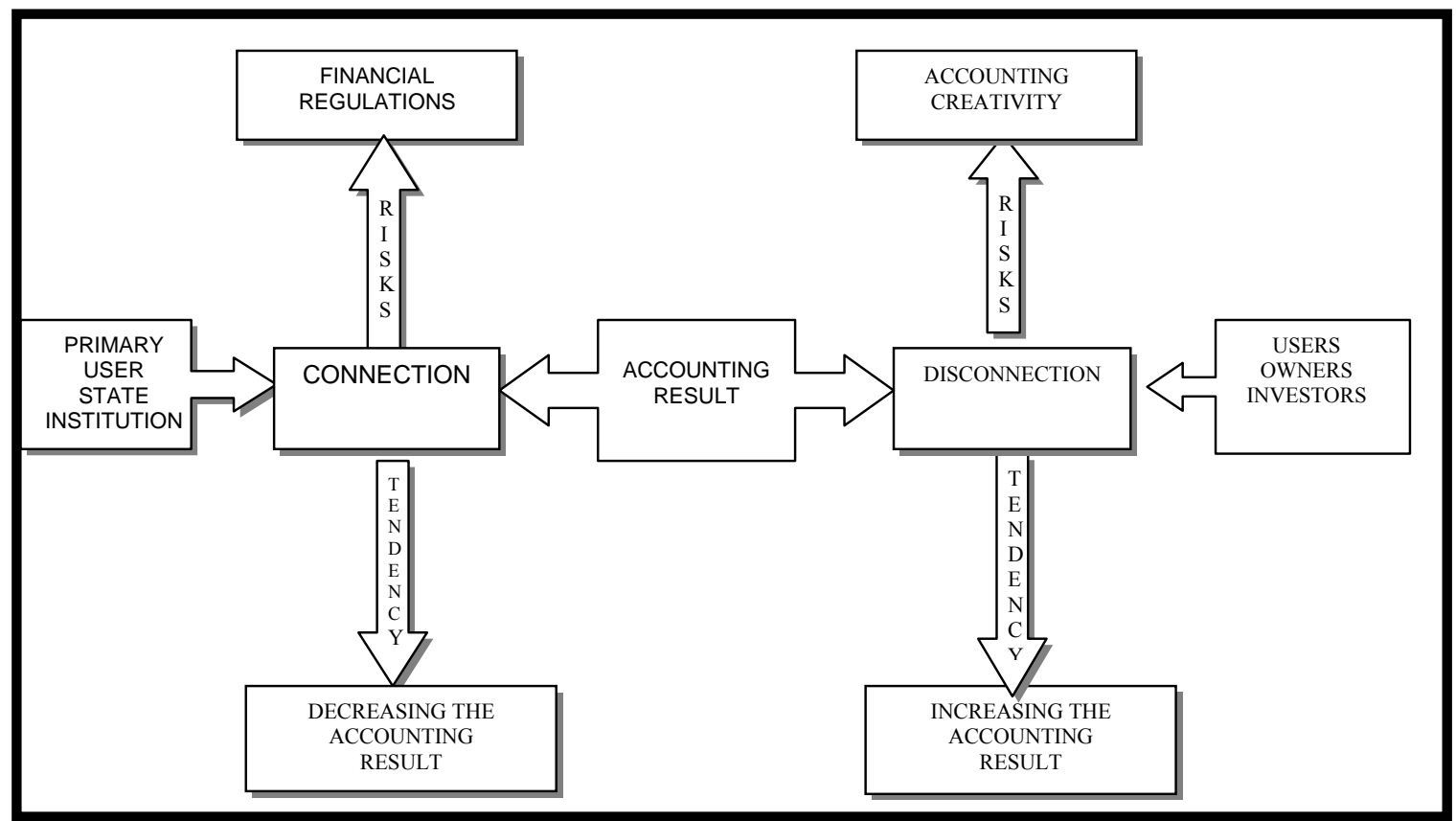

Figure no. 3. - Systems connected and disconnected to taxation, (authors processings)

If in the case of accounting systems connected to taxation, the danger for accounting was represented by the authority of tax regulations, in the case of accounting systems disconnected from taxation, the risk of distorting the accounting information results comes from accounting creativity. In the last case, the consequence might be quite serious. Although is being induced the tendency of an accounting profit increase which would satisfy the investors in their quality of main users of accounting information, the society risks to pay dividends relying on an unreal profit (artificially increased also by the inevitable inflationary phenomenon), and, as a consequence, it will be undercapitalized.

Certainly, there are some possibilities to protect investors in order to discover the creative accounting techniques:

- $\quad$ attentively consulting the information presented at the end of the annual report regarding details of financial situations;

- $\quad$ consulting and evaluating change opportunities in accounting policies, as well as the impact they have on financial information;

- monitoring for a period of several years the transfers between the balance sheet and the profit and loss account. In the economies in which the capital market has a great importance in financing, calculating and reporting the result per share is of vital importance. If the evolution of this indicator is unusually constant or it registers significant evolutional differences from one financial year to another it is very likely that creative techniques are used;

- $\quad$ paying a lower importance to the profit and loss account and to the accounting result, and evaluating it through cash flow. Financial imagination can increase the result, the shareholders equity or it can transform assets in receivables, but it can generate liquidities to a lesser extent. Or, the orientation of external users towards cash flow might discourage managers to use creativity. 


\section{Conclusions}

The concept of true and fair view origin is Anglo-Saxon (true and fair view) being first used in 1947 in the UK Company Law (Companies Act) which stated: "every balance sheet of a company must give a true and fair view of the business company at the end of year, and every profit and loss account of a company must give a true and fair view of its results for the financial year" (Feleaga L. şi Feleagă N., 1996). It must be mentioned that this concept "true and fair value" has never been explicitly defined within English accounting regulations.

Moreover, the concept of true and fair view is relative, every user of accounting information having a certain perception upon what true and fair view means. The equivalent of true and fair view within French accounting is honesty, which emerged in the French law in 1937.

Honesty was intended to be elevated to the rank of qualitative criterion which would have served as reference when controlling the reliability of accounting message. In an absolute conception, it corresponds to the desire to be close to reality. The honesty treated by the French system has gradually diverged from the British true and fair view by the fact that it became empty of content, because honesty was associated with conformity with rules, which meant respecting the rules required by laws, regulations, customs (Bernheim Y., 2002). By analyzing this definition we can affirm (Black J. şi Amat O., 1993) in the struggle against creative accounting: is ,true and fair view" part of the problem or part of the solution?:

- References to the reasonable estimates and within current accounting practices, involves a certain tolerance towards some inevitable accuracy. It is preferable to approximate rather than precisely wrong, said J.M Keynes, which may explain the replacement of requirement of true and correct view with the true and fair view. Viewed from this perspective, the true and fair view can be considered an incentive to use creative accounting techniques;

- The most objective picture possible means neutral, and this is already present in the accounting rules. Neutrality means that the financial statements, through the selection and presentation of information, should not affect decisions and judgments of users of accounting information in order to lead to a predetermined result. Analyzed from this angle, true and fair view is against the use of creative accounting techniques;

- $\quad$ The references to omissions and the letter and spirit of the law have led some believe that true and fair view requirement is more rigorous: true means the letter of law and fair represents the spirit. Analyzed from this point of view, true and fair view is against the use of creative accounting techniques;

- If a court had to decide if a company's financial situations provide or not a true and fair view, it would be difficult to identify other evaluation criteria than the conformity with generally accepted accounting principles. Analyzed from this point of view, true and fair view is pro using creative accounting techniques.

Therefore, creative accounting has a negative role upon achieving true and fair view if the flexibility allowed by accounting norms is used to achieve certain reports in favor of a confined number of accounting information users, in the detriment of their majority.

In general, the continental accounting system considers that creative accounting is an obstacle in achieving true and fair value, being a deceptive and undesired practice, while the AngloSaxon accounting system proves a greater flexibility and evaluates creative accounting as being necessary in order to be in step with the economic, social or legal evolutions.

\section{Acknowledgements}

This work was supported from the European Social Fund through Sectorial Operational Programme Human Resources Development 2007-2013, project number POSDRU /89/1.5/S/59184 „Performance and excellence in postdoctoral research in Romanian economics science domain”. 


\section{References}

1. Bernheim Y., 2002. La comptabilité d'intention: bonne ou mauvaise intention?, Revue de droit comptable

2. Black J., Amat O., 1993. European accounting, Publisher Pitman, London.

3. David A., Britton A., 2002. Financial reporting, sixth edition, Publisher Thompson Learning, London.

4. Feleagă N., 1996. Controverse contabile, Publisher Economică, Bucureşti.

5. Harvey D., Mclaney E., Atrill P., 2001, Accounting for business, third edition, Publisher Butterworth-Heinemann, London.

6. Malcolm S., 2005. Research methods in accounting, Publisher SAGE Ltd., London.

7. Ristea M., Manolescu M., Petre G., 2005. Ghid practic de reconciliere contabilitatefiscalitate, Publisher C.N. Imprimeria Națională S.A., Bucureşti.

8. Solomons D., 1989. Guidelines for Financial Reporting, Publisher ICAEW, London.

9. Stolowy H., 1994. Existe-t-il vraiment une comptabilité créative?, Revue de droit comptable.

10. Walton P., Haller A., Raffournier B., 2003. International accounting, Publisher Thompson learning, London. 